\title{
Surgical interventions during pregnancy due to nontumor- like lesions and non-malignant and malignant genital
} cancers

\author{
Dobrosława L Sikora-Szczęśniak* and Maciej Szczesniak \\ Department of Gynecology and Obstetrics, Head of the Department, Poland
}

\begin{abstract}
Aim: The aim of study was to evaluate the results of treatment in pregnant women with various pathologies and benign neoplasms of the genital organs which required surgical management.

Material and methods: A retrospective analysis covered medical records of 33 pregnant women hospitalized in 1998-2017 operated on for pathologies affecting genital organs. The following parameters were assessed: age of patients, gestational age at the time of treatment, type of treatment, intraoperative histopathological diagnosis, and further course of pregnancy.

Results: Gynecological pathologies were diagnosed in 33 out of 44 (75\%) pregnant women undergoing surgical operations/procedures in the 20-year period. Those included one case of pre-invasive carcinoma of the uterine cervix in early pregnancy, two cases of mucous cystadenoma of borderline malignancy detected intraoperatively on histopathological examination. In 25 women, internal pathologies were operated on by laparotomy, and in two women by laparoscopy. Vaginal procedures and operations, i.e. ovarian and peri-salpingeal cyst punctures and cervical amputations were performed in 3 and 1 patient respectively. Serous, follicular, and corpus luteum ovarian cysts were the most numerous (11-33.3\%) in the group of gynecological diseases. Operations for diseases and injuries of external genital organs were performed in 2 women. One of the women had a miscarriageon the 4th day after gynecological surgery. Another one left the Department with her pregnancy intact on the second day after surgery and did not report for further consultation. There were 3 (9.7\%) premature births in 31 of 33 pregnant women operated on for gynecological diseases.
\end{abstract}

Conclusions: Surgical treatment in pregnancy due to genital disorders should be individualized, taking into account clinical symptoms, gestational age, results of imaging and laboratory examinations, and the woman's preferences. Surgical treatment due to gynecological diseases in pregnancy is associated with the risk of complications for the patient and obstetric failures such as miscarriages and premature births.

\section{Introduction}

Cervical cancer is the most frequent malignancy in pregnancy with the incidence of $0.8-15.5 / 10,000$ pregnancies. If cervical cancer is suspected in pregnancy, diagnostic cervix conization is recommended between 14 and 20 hbd [1]. Neoplastic lesions in the adnexa occur in $0.5-2.2 \%$ pregnant women [2], and ovarian malignancies in 1 out of 15, 000-32, 000 pregnancies [3].

Some reports estimate the incidence of ovarian cancer as 1 per 10, $000-100,000$ pregnancies [4-8]. In the studies cited by Ngu et al. ovarian cancer in pregnancy was diagnosed in 1 per $5,000-1$ per 47,000 live births. However, the authors themselves reported these changes as 1 per 10, 000 live births [9].

Ovarian cancer is the most frequent among ovarian malignancies detected in pregnant women (49-75\%), diagnosed in 1 per $15,000-32$, 000 pregnancies. The incidence of gonadal malignancies is $9-16 \%$, and germinal tumors $6-40 \%[7,10,11]$.

The occurrence of ovarian malignancies and borderline ovarian tumors (BOT) in pregnant women varies from $2-3 \%$ to $2.15-13 \%$. BOTtypes are usually found in women at reproductive age; on average at the age of 38-45 years [4,6,8,11-13]. Among ovarian tumors, BOTs occur in 21 to $35 \%$ cases $[5,7]$. However, among ovarian cancers, they occur in more than $2 / 3$ cases [14]. According to WHO, the basic criterion for borderline tumor is the absence of destructive invasion of the stroma [15].

Surgical treatment in pregnant women should be individualized, taking into account clinical symptoms, gestational age, results of imaging and laboratory investigations, and women's preferences. According to the literature, laparoscopy was the preferred technique in women with ovarian cysts of $<10-\mathrm{cm}$ in diameter, and laparotomy in the cysts of $>10-\mathrm{cm}$ in diameter [9]. However, laparoscopy performed in the first trimester of pregnancy may pose a greater risk to the fetus [16]. Ngu et al. did not find any significant differences in obstetric outcomes between the groups of women operated on before 20th hbd

*Correspondence to: Dobrossawa L Sikora-Szczssniak, Gynecological Ward. Radom, Poland, Radomski Specialist Hospital, 26-610 Radom, Tochtermana, Poland, E-mail: dosiass@wp.pl

Key words: ovarian tumors, ovarian carcinoma, pregnancy

Received: September 06, 2019; Accepted: September 20, 2019; Published: September 24, 2019 
by laparoscopy and laparotomy due to pathological changes in the appendages [9]. Some authors preferred laparotomy, though [17].

The most common cause of surgery undertaken in pregnancy are pathologies in the adnexa. Most of them are ovarian tumors diagnosed in 1 per 1,000 pregnancies [18]. Surgical treatment in pregnancy is recommended in the second trimester if it is possible at all. This is often due to the resorption of the lesions that were detected on ultrasound examination in the first trimester of pregnancy, e.g. luteal and tekaluteine cysts, when the progesterone production is taken over by the placenta, and after the completion of organogenesis [19].

In addition, ovarian endometriomas tended to decrease in size during pregnancy [20].

Complications associated with genital disorders in pregnancy include torsions and ruptures that may result in hemorrhage or evacuation of the cyst content to the peritoneal cavity, which is dangerous for a woman in the case of malignancy (possible progression of cancer) or dermoid cyst (possible chemical peritonitis) [21,22]. Surgical removal of adnexal cysts allows for the avoidance of acute complications such as torsion, ovarian cyst rupture, and delayed diagnosis of malignant disease [23].

The torsion of the appendages concerns mainly women at reproductive age. The right adnexa are more often (67-71\%) twisted than on the left side. Currently, the incidence of ovarian cyst torsion is estimated at $2-7 \%$ [24]. The twist of the fallopian tube itself may be associated with hygromas or peri-salpingeal cysts which can also be twisted. Samborska et al. noted that among serous cysts of the adnexa found during Cesarean section, $61 \%$ were peri-salpingeal cysts, which are usually serous cysts. They are mentioned as one of the etiological factors likely to result in salpingeal torsion during pregnancy $[25,26]$.

Heterotopic pregnancy (HP) is a rare complication of pregnancy in which both ectopic pregnancy (EP) and intrauterine pregnancy (IUP) coexist. Clinical symptoms of HP are atypical, while about $50 \%$ of patients with HP may have no symptoms in the early period. Therefore, an early and accurate diagnosis is often difficult [27-30]. An important role in the diagnosis is transvaginal USG. However, based on the literature reviews from 1971-1993 and 1994-2004 approximately 59\% and $74 \%$ of HP cases were not confirmed until after surgery respectively [31]. The treatment options include the removal of ectopic pregnancy by laparotomy or laparoscopy aside the transvaginal aspiration of ectopic embryo. However, treatment experience is limited as HP is a very rare pathology [32].

Uterine myomas occur in about $25 \%$ of women at procreation age [33]. In the last decades, the fertility period of women has extended. It is also more common to make decisions about having the first and next baby at the later age. The above-mentioned phenomena affect the increased incidence of ovarian malignancies and uterine myomas in pregnant women [34,35]. Many authors have noted increased occurrence of uterine myomasin pregnant women aged over 35 [36,37].

\section{Material and methods}

In the period from 1998 to 2017 in the Department of Gynecology and Obstetrics, Regional Specialist Hospital in Radom, Poland there were 36, 671 deliveries, including 26, 490 natural deliveries $(72.2 \%)$, and $10,181(27.8 \%)$ by Caesarean section. The analysis included 33 pregnant women who underwent gynecological operations due to diseases affecting their genital organs.

\section{Results}

Gynecological diseases (33 cases out of 44) accounted for $75 \%$ surgeries performed in pregnancy. Tables 1-4 show respectively:

- type of surgical operations/procedures performed,

- results of postoperative histopathological examinations,

- age of patients and gestational age on the day of surgery and delivery,

- list of operations and procedures with account for trimesters of pregnancy.

Diagnostic tests providing insight view into genital organs included ultrasonography and, if necessary, magnetic resonance imaging (MRI). MRI is characterized by high sensitivity and can be performed at any stage of pregnancywithout gadolinium $[38,39]$. The highest frequency

Table 1. Surgical interventions in pregnancy [ $\mathrm{N}=33]$

\begin{tabular}{|c|c|c|c|c|c|c|c|c|c|c|c|c|c|c|c|c|}
\hline \multirow[t]{3}{*}{$\begin{array}{l}\text { Type of } \\
\text { surgery }\end{array}$} & & & & & & $\begin{array}{c}\text { Cyst } \\
\text { puncture } \\
\text { of left } \\
\text { ovary }\end{array}$ & $\begin{array}{c}\text { Left } \\
\text { salpingectomy }\end{array}$ & \multicolumn{2}{|c|}{$\begin{array}{l}\text { Excision of peri- } \\
\text { salpingeal cyst }\end{array}$} & \multicolumn{2}{|c|}{$\begin{array}{c}\text { Puncture of } \\
\text { pari-salpingeal } \\
\text { cyst }\end{array}$} & \multicolumn{2}{|c|}{$\begin{array}{l}\text { Myoma (i): - } \\
\text { excision }\end{array}$} & $\begin{array}{c}\text { Amputation } \\
\text { of uterine } \\
\text { cervix }\end{array}$ & $\begin{array}{c}\text { Excision of } \\
\text { cyst from } \\
\text { Bartholin } \\
\text { gland }\end{array}$ & $\begin{array}{c}\text { Hematoma } \\
\text { of labia }\end{array}$ \\
\hline & \multicolumn{2}{|c|}{ Adnexectomy } & $\begin{array}{c}\text { Left } \\
\text { salpingectomy } \\
\text { with cyst } \\
\text { removal }\end{array}$ & \multicolumn{2}{|c|}{$\begin{array}{c}\text { Excision/ } \\
\text { enucleation of } \\
\text { ocarian cyst }\end{array}$} & $n=1$ & $n=2$ & \multicolumn{2}{|c|}{$n=3$} & \multicolumn{2}{|c|}{$\mathrm{n}=\mathbf{2}$} & \multicolumn{2}{|c|}{$\begin{array}{c}\text { - exploratory } \\
\text { surgery }\end{array}$} & \multirow[t]{3}{*}{$n=1$} & \multirow[t]{2}{*}{$n=1$} & $\begin{array}{c}\text { Evacuation } \\
\text { of } \\
\text { hematoma }\end{array}$ \\
\hline & \multicolumn{2}{|c|}{$\mathbf{n}=\mathbf{5}$} & $n=3$ & \multicolumn{2}{|c|}{$n=11$} & & & & & & & \multicolumn{2}{|c|}{$\mathbf{n}=\mathbf{3}$} & & & $\mathrm{n}=1$ \\
\hline Route & $\begin{array}{l}\text { left } \\
\text { side }\end{array}$ & $\begin{array}{l}\text { right } \\
\text { side }\end{array}$ & & $\begin{array}{l}\text { left } \\
\text { side }\end{array}$ & $\begin{array}{l}\text { right } \\
\text { side }\end{array}$ & - & - & $\begin{array}{l}\text { left } \\
\text { side }\end{array}$ & $\begin{array}{l}\text { right } \\
\text { side }\end{array}$ & $\begin{array}{l}\text { left } \\
\text { side }\end{array}$ & $\begin{array}{l}\text { right } \\
\text { side }\end{array}$ & $\begin{array}{l}\text { left } \\
\text { side }\end{array}$ & $\begin{array}{l}\text { right } \\
\text { side }\end{array}$ & & right side & right side \\
\hline $\begin{array}{l}\text { Lower } \\
\text { medline } \\
\text { incision }\end{array}$ & 1 & 1 & 3 & 1 & $3^{\mathrm{xxxx}}$ & - & 1 & 1 & $1^{\mathrm{x}}$ & - & - & \multicolumn{2}{|c|}{$2^{\mathrm{X}}$} & - & - & - \\
\hline $\begin{array}{l}\text { Lower } \\
\text { pararectus } \\
\text { incision }\end{array}$ & 1 & - & - & 1 & - & - & - & - & - & - & - & - & 1 & - & - & - \\
\hline $\begin{array}{c}\text { Pfannenstiel } \\
\text { incision }\end{array}$ & 2 & - & - & $2^{\mathrm{Xx}}$ & 3 & - & $1^{\mathrm{xxx}}$ & - & - & - & - & - & - & - & - & - \\
\hline Laparoscopy & - & - & - & & 1 & - & - & - & 1 & - & - & - & - & - & - & - \\
\hline Vaginal route & - & - & - & - & - & 1 & - & - & - & 1 & 1 & - & - & 1 & - & - \\
\hline Other & - & - & - & - & - & - & - & - & - & - & - & - & - & - & 1 & 1 \\
\hline
\end{tabular}

$1^{\mathrm{x}}$-lateral peri-salpingeal cysts coexisting with uterine body myomas; $1^{\mathrm{xx}}-$ coexisting left peri-salpingeal cyst with ovarian cyst; $1^{\mathrm{xxx}}-$ coexisting peri-salpingeal cyst with 3 -fold torsion of the fallopian tube; $1^{\mathrm{XXXx}}-$ release of adhesions and reposition of retrograde uterus 
Sikora-Szczesniak DL (2019) Surgical interventions during pregnancy due to nontumor-like lesions and non-malignant and malignant genital cancers

Table 2. Histopathological results in cases of treatments and surgery in women who underwent surgery during pregnancy $(\mathrm{N}=33)$

\begin{tabular}{|c|c|c|c|c|c|c|c|c|c|c|c|c|c|c|c|}
\hline \multirow{2}{*}{$\begin{array}{c}\begin{array}{c}\text { Type of surgery/ } \\
\text { procedure }\end{array} \\
\begin{array}{c}\text { Histopathological } \\
\text { diagnosis }\end{array}\end{array}$} & \multicolumn{2}{|c|}{$\begin{array}{c}\text { Adnexectomy } \\
\mathbf{N}=5\end{array}$} & \multirow[t]{2}{*}{$\begin{array}{c}\text { Left } \\
\text { salpingectomy } \\
\text { with cyst } \\
\text { removal } N=3\end{array}$} & \multicolumn{2}{|c|}{$\begin{array}{c}\text { Excision/enucleation } \\
\text { of ocarian cyst } N=9\end{array}$} & \multirow{2}{*}{ 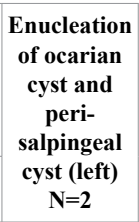 } & \multirow[t]{2}{*}{\begin{tabular}{|c|}
$\begin{array}{c}\text { Puncture } \\
\text { of the } \\
\text { ovarian } \\
\text { cyst } \\
\text { (right) } \\
\mathrm{N}=1\end{array}$ \\
\end{tabular}} & \multirow[t]{2}{*}{$\begin{array}{l}\text { Salpingectomy } \\
\text { (left) } N=2\end{array}$} & \multicolumn{2}{|c|}{$\begin{array}{c}\text { Perisalpingectomy } \\
\mathbf{N}=\mathbf{3}\end{array}$} & \multicolumn{2}{|c|}{$\begin{array}{c}\text { Puncture } \\
\text { of peri- } \\
\text { salpingeal } \\
\text { cyst } \mathrm{N}=2\end{array}$} & \multicolumn{2}{|c|}{$\begin{array}{l}\text { Exploratory } \\
\text { laparotomy } \\
\text { Myomectomy. } \\
\text { Amputation } \\
\mathbf{N}=4\end{array}$} & \multirow{2}{*}{\begin{tabular}{|c}
$\begin{array}{c}\text { Cystectomy. } \\
\text { Evacuation } \\
\text { of hematoma } \\
\mathbf{N}=\mathbf{2}\end{array}$ \\
right side
\end{tabular}} \\
\hline & left & right & & left & right & & & & left & right & left & right & body & cervix & \\
\hline $\begin{array}{c}\text { Mucous } \\
\text { cystadenoma of } \\
\text { the ovary with a } \\
\text { focus of borderline } \\
\text { malignancy }\end{array}$ & 1 & 1 & & & & & & & & & & & & & \\
\hline $\begin{array}{c}\text { Mucous } \\
\text { cystadenoma, } \\
\text { cystoma, mucous } \\
\text { cyst }\end{array}$ & & 1 & & 1 & 1 & & & & & & & & & & \\
\hline \multirow{2}{*}{ Luteal cyst } & & & & \multicolumn{2}{|c|}{$1^{\mathrm{x}}$} & & & & & & & & & & \\
\hline & & & & & 1 & 1 & & & & & & & & & \\
\hline $\begin{array}{c}\text { Dermatoid cyst of } \\
\text { the ovary }\end{array}$ & & & 3 & 1 & & & & & & & & & & & \\
\hline $\begin{array}{c}\text { Serous, luteal cyst(s) } \\
\text { mucous cystoma }\end{array}$ & 2 & & & & 3 & 1 & $1^{\mathrm{xx}}$ & & 1 & 2 & 1 & 1 & & & \\
\hline Endometrial cyst & & & & & 1 & & & & & & & & & & \\
\hline $\begin{array}{l}\text { Heterotopic } \\
\text { pregnancy }\end{array}$ & & & & & & & & 1 & & & & & & & \\
\hline $\begin{array}{c}\text { Torsion of the } \\
\text { fallopian tube with } \\
\text { peri-salpingeal cyst }\end{array}$ & & & & & & & & 1 & & & & & & & \\
\hline $\begin{array}{l}\text { Myoma (i) of the } \\
\text { uterus } \\
\text { Preinvasive tumor of } \\
\text { the uterine cevix }\end{array}$ & & & & & & & & & & & & & 3 & 1 & \\
\hline $\begin{array}{c}\text { Cyst of the Bartholin } \\
\text { gland } \\
\text { Post-traumatic } \\
\text { hematoma of the } \\
\text { labia }\end{array}$ & & & & & & & & & & & & & & & 2 \\
\hline
\end{tabular}

$1^{\mathrm{X}}$ - bilateral cysts; $1^{\mathrm{xx}}$ - surgery after delivery:- Cystadenofibroma ovarii dex

Table 3. Age of patients and gestational age on the operation day/day of treatment and delivery $(\mathrm{N}=31 / 33)$

\begin{tabular}{|c|c|c|c|}
\hline Parameter & Mean & Range \\
\hline Age of the pregnant woman $(\mathrm{N}=33)$ & 28.88 & $20-41$ \\
\hline Gestational age on the day of surgery $(\mathrm{N}=33)$ & 15.09 & $6-37$ \\
\hline Gestational age on the day of delivery $(\mathrm{N}=31)$ & 38.39 & $40-33$ & 7.36 \\
\hline
\end{tabular}

Table 4. The list of operations and treatments due to non-neoplastic changes and genital diseases in each trimester of pregnancy ( $\mathrm{N}=33$ )

\begin{tabular}{|c|c|c|c|c|c|c|c|c|c|c|c|c|c|c|c|}
\hline \multirow{2}{*}{$\begin{array}{c}\text { Trimester } \\
\text { on the } \\
\text { day of } \\
\text { surgery } \\
\mathrm{N}(\%) .\end{array}$} & \multicolumn{2}{|c|}{ Adnexectomy $n=5$} & \multirow{2}{*}{$\begin{array}{c}\text { Left } \\
\text { salpingectomy } \\
\text { with cyst } \\
\text { removal } n=3\end{array}$} & \multicolumn{2}{|c|}{$\begin{array}{c}\text { Excision/ } \\
\text { enucleation } \\
\text { of cyst from } \\
\text { ovaries }(n=1) \\
\text { ovary }(n=10)\end{array}$} & \multirow[t]{2}{*}{$\begin{array}{c}\text { Puncture } \\
\text { of right } \\
\text { ovarian } \\
\text { cyst } n=1\end{array}$} & \multirow[t]{2}{*}{$\begin{array}{c}\text { Excision } \\
\text { of the left } \\
\text { ovary } \\
n=2\end{array}$} & \multicolumn{2}{|c|}{$\begin{array}{c}\text { Excision of peri- } \\
\text { salpingeal cyst } \\
\quad n=3\end{array}$} & \multicolumn{2}{|c|}{$\begin{array}{c}\text { Puncture of } \\
\text { peri-salpingeal } \\
\text { cyst } n=2\end{array}$} & \multirow{2}{*}{$\begin{array}{l}\text { Myoma } \\
\text { ( i ): - } \\
\text { excision - } \\
\text { exploratory } \\
\text { surgery } \\
\text { n=3 }\end{array}$} & \multirow{2}{*}{$\begin{array}{c}\text { Amputation } \\
\text { of the } \\
\text { uterine } \\
\text { cervix } \\
n=1\end{array}$} & \multirow{2}{*}{$\begin{array}{c}\text { Excision } \\
\text { of cyst } \\
\text { from } \\
\text { Bartholin } \\
\text { gland } \\
\text { n=1 } \\
\text { Right } \\
\text { side }\end{array}$} & \multirow[t]{2}{*}{$\begin{array}{l}\text { Hematoma of } \\
\text { the labia } n=1 \\
\text { Right side }\end{array}$} \\
\hline & Left side & $\begin{array}{c}\text { Right } \\
\text { side }\end{array}$ & & $\begin{array}{l}\text { Left } \\
\text { side }\end{array}$ & $\begin{array}{l}\text { Right } \\
\text { side }\end{array}$ & & & $\begin{array}{c}\text { Left } \\
\text { side }\end{array}$ & $\begin{array}{c}\text { Right } \\
\text { side }\end{array}$ & $\begin{array}{c}\text { Left } \\
\text { side }\end{array}$ & $\begin{array}{l}\text { Right } \\
\text { side }\end{array}$ & & & & \\
\hline $\begin{array}{c}\text { Trimester } \\
\mathrm{I} \\
\mathrm{N}=13 \\
(39.4 \%)\end{array}$ & 2 & & 2 & 1 & 4 & & 2 & & 1 & - & - & - & 1 & - & - \\
\hline \multirow{2}{*}{$\begin{array}{c}\text { Trimester } \\
\text { II } \\
\mathrm{N}=18 \\
(54,5 \%)\end{array}$} & \multirow[b]{2}{*}{2} & \multirow[b]{2}{*}{1} & \multirow[b]{2}{*}{1} & \multicolumn{2}{|c|}{1} & \multirow[b]{2}{*}{1} & \multirow[b]{2}{*}{-} & \multirow[b]{2}{*}{1} & \multirow[b]{2}{*}{ - } & \multirow[b]{2}{*}{1} & \multirow[b]{2}{*}{1} & \multirow[b]{2}{*}{3} & \multirow[b]{2}{*}{ - } & \multirow[b]{2}{*}{ - } & \multirow[b]{2}{*}{1} \\
\hline & & & & 3 & 2 & & & & & & & & & & \\
\hline $\begin{array}{c}\text { Trimester } \\
\text { III } \\
\mathrm{N}=2 \\
(6.1 \%)\end{array}$ & - & - & - & - & - & - & - & - & $1^{x}$ & - & - & - & & 1 & - \\
\hline
\end{tabular}


of cyst detection in the ovaries was noted in the first trimester of pregnancy. Szczepańska et al. diagnosed ovarian tumors (96.5\% cases) in the first trimester of pregnancy [17].

Cancer markers CA-125 antigen, $a$-fetoprotein, lactate dehydrogenase, and B-HCG have little diagnostic value as they are elevated in physiological pregnancy, especially in the first trimester $[11,14]$. Also, in diagnostically difficult cases, laparoscopy which itself is a surgical treatment may be diagnostically used, too.

Preoperatively, one case of preinvasive carcinoma of the cervix was diagnosed. Cervical conization was performed in a 20 -year-old woman in 7th hbd of her first pregnancy. Due to intrauterine infection of the fetus and marginal placenta previa the pregnancy was terminated in 35th hbd by Caesarean section. A newborn male was born, weighing 2990 g, scoring 7 on Apgar scale.

Intraoperative histopathological examination found 2 cases of mucous cystadenoma of borderline malignancy. Both patients underwent laparotomy from midline incision. One woman aged 30, pregnancy II, 14th hbd, underwent right adnexectomy. She gave birth (natural delivery) at 40th hbd to a son, body weight $3900 \mathrm{~g}, 10$ Apgar score. The other patient, a 32-year old, pregnancy I, had left adnexectomy in $16^{\text {th }} \mathrm{hbd}$. She gave birth by Caesarean section to a son, weighing 2, $480 \mathrm{~g}$ at 38th hbd, Apgar score 10, with signs of intrauterine dystrophy. On Caesarean section right appendages were inspected and turned out to be intact. Swabs were taken from under the diaphragm dome, and the omentummajus resected. Further exploration of the peritoneal cavity found smooth liver, extra-peritoneal lymph nodes normal, and other abdominal organs appeared normal on palpation.

Among 32 out of 33 operated pregnant women, 1 (3.0\%) had a miscarriage. In the group of 31 out of 33 women preterm delivery was recorded in $3(9.7 \%)$ cases.

Surgeries in pregnancy were carried out by:

- laparotomy-in 25 (75.6\%) cases

- laparoscopy-in 2 (6.1\%) cases

- vaginal route-in $3(9.1 \%)$ cases

- transabdominal cyst puncture-in 1 (3.1\%) case.

Other operations were performed in $2(6.1 \%)$ of pregnant women. In two cases $(6.1 \%)$ laparotomy was performed after conversion from laparoscopy. In one case in a 36-year-old woman, pregnancy IV, 12th hbd the decision to operate on was made because of the macroscopically suspicious cyst, which eventually turned out to be a cyst of the corpus luteum. In the other case, ectodermal cyst and serous cystoma of the left ovary were detected in a 28 -year-old pregnant woman, pregnancy I, 7th hbd, transition to laparotomy occurred after the detection of multiple adhesions in the pelvis minor. Laparotomy was performed in $18(54.5 \%)$ patients, and laparoscopy in $1(3.0 \%)$ case.

Right ovarian cyst, 80 x $60 \mathrm{~mm}$, displaced to the Pouch of Douglas was punctured in one $(3.0 \%)$ case, in a 22 -year-old woman, 14 th hbd, pregnancy I. Under general anesthesia, a needle was inserted into the cyst, USG -guided, approached from the vaginal fornix, and about $230 \mathrm{ml}$ of serous fluid evacuated from the cyst, which was sent for histopathological examination. Ovarian cysts were found again during hospitalization in 36th hbd due to threatening preterm delivery. She delivered naturally after 40 th hbd. A baby-girl was born, body weight 3960 g, Apgar score 10. The mother and the baby were discharged from the Ward on the third day after giving birth. Three months later the cyst in the right ovary, $57 \mathrm{x} 39 \mathrm{~mm}$ was excised by laparoscopy. Intra- and postoperative histopathology confirmed right ovarian cyst - Cystadenfibroma, fragment of the left ovary-Cystis follicularis ovarii. She was discharged from the Ward on the second day after surgery.

The results of postoperative histopathological examinations are presented in Table 2.

Ovarian tumors (20 cases-60.6\%) were the main cause of pathologies of the genital organs. In this group the most numerous were serous cysts (7 cases-35\%), mucous cystadenomas, cystoma and mucous cysts ( 5 cases-25\%). Among them, two cases of borderline mucous cystadenomas constituted $10 \%$ of ovarian tumors and $6.1 \%$ of genital pathologies requiring surgical treatment followed by dermoid cyst ( 4 cases-20\%), cyst of the corpus luteum (3 cases-15\%), and endometrioma (1 case-5\%).

Incarceration of the gravid uterus with acute urinary retention and coexisting ectodermal cyst of the right ovary required surgery (in a 28 -year-old woman in 14th hbd). It was related to the history of past laparotomy at the age of 18 , the enucleation of the left ovarian dermoid cyst, and resection of the right ovary fragment. In addition, during the operation the adhesions of the left ovary to the sigmoid fixing the uterus in the pelvis minor were detected. The ovarian cyst was resected, adhesions released, and the pregnant uterus dislodged from the pelvis minor. After surgery, further course of the pregnancy was uneventful. In 40 th hbd the patient gave birth to a son (natural delivery), body weight of 2970g, Apgar score 10.

Adnexal torsion (3-fold) accompanied by ovarian serous cyst was detected in 2 cases, and 1-fold twist in 2 cases: in the patient in 9th hbd, pregnancy $\mathrm{V}$, with the presence of a serous cyst in the right ovary, and in 7 th hbd, pregnancy I, with a cyst of the corpus luteum in the left ovary and coexisting peri-salpingeal cyst.

Ovarian (left) rupture was recorded in 2 pregnant women: the one in $18 \mathrm{hbd}$, pregnancy III, with cysts os the corpus luteum in both ovaries, and the other in $9 \mathrm{hbd}$ with 3 -fold torsion of the left appendages.

Peri-salpingeal mucous cysts (6 cases-18.2\%) were the second reason for surgeries in the group of 33 pregnant women. Laparotomy and laparoscopy were performed in 3 and 1 patient respectively, perisalpingeal cysts were punctured in two patients.

In a 26-year old patient, 14th hbd, the peri-salpingeal cyst of $93 \times 88$ $\mathrm{mm}$ was punctured in the operating room conditions. Puncture needle was inserted into the posterior vaginal fornix, and approximately 100 $\mathrm{ml}$ of blood-streaked serous fluid evacuated. The delivery by Caesarean section was decided in 39th hbd due to cephalopelvic disproportion. On Caesarean section, bilateral cysts were dissected (histopathological examination confirmed Cystis cilioepithelialis). The mother and her newborn male, body weight of $3420 \mathrm{~g}$, Apgar score of 10 were discharged from the Ward on the 6th day after giving birth.

In a 26 -year-old female patient, 17th hbd, pregnancy I, transabdominal puncture was performed twice. Right peri-salpingeal cyst of $150 \mathrm{~mm}$ in diameter was punctured and a total of $510 \mathrm{ml}$ of serous fluid evacuated. The Caesarean section was performed in 35 th hbd due to the premature rupture of the amniotic sac. On Caesarean section, a rightsided peri-salpingeal cyst was dissected (histopathological examination confirmed Cystis serosa perisalpingealis et fimbriae oviducti). A male, body weight of $2410 \mathrm{~g}$, Apgar score of 7 with features of prematurity and intrauterine infection was born. He was discharged from the Ward on the 14th day after birth weighing $2510 \mathrm{~g}$. 
Torsion of peri-salpingeal cyst was noted in 2 cases. One, in a patient in 37 th $\mathrm{hbd}$, pregnancy II, a 1 -fold peri-salpingeal cyst was dissected and Caesarean section performed. In the other case, in the patient in 13th hbd a 3-fold twisted peri-salpingeal cyst and the left fallopian tube were excised.

In the case of an 11-week heterotopic pregnancy (HP) ultrasound examination detected ectopic pregnancy in the left fallopian tube and bleeding into the peritoneal cavity. The left fallopian tube and the ectopic pregnancy were removed by laparotomy from the lower median incision. Histopathological examination confirmed the fallopian tube widened up to $30 \mathrm{~mm}$, and the $22-\mathrm{mm}$ fetus in its lumen. The further course of her pregnancy was uneventful. The patient delivered naturally (pregnancy III) in 37th hbd.

Three pregnant women (9.1\%) were operated on for uterine myomas. In two cases myomectomy was performed. In one patient, coexisting ovarian tumor was suspected, and exploratory laparotomy performed. Other 2 (6.1\%) women were operated on for the cysts of the Bartholin gland and vulvar hematoma.

\section{Discussion}

Operative procedures performed during pregnancy are associated with the risk of pregnancy loss, premature delivery, and fetal immaturity. However, in acute conditions detected in genital organs, the decision about surgical treatment should be made immediately. The goal of treatment is to avoid complications associated with postponed surgery or disease progression in the case of cancer [21].

Cervical preinvasive cancer at the initial stage of invasion was diagnosed in early pregnancy. According to the standards of cancer management in pregnant women, oncological consultation of the patient, including histopathology and colposcopy took place at the Oncology Center, Institute in Warsaw [1]. Cervical conization was recommended and performed at $7 \mathrm{th} h \mathrm{hd}$. Histopathological examination confirmed Carcinoma planoepithelialepraeinvasivumtypusprogrediens cum invasion punctate superficialisfocalis, Condylomaplanum. The pathological region was removed with healthy margins.

Moreover, the postponement of surgery in the case of ovarian cancer can lead to complications such as torsion or rupture of ovarian cysts complicating the further course of pregnancy and endangering the patient's health and life $[16,23,40]$. The best period for surgical treatment in pregnancy, including laparoscopy, is the second trimester, up to $23 \mathrm{rd}$ hbd. In the presented material $54.5 \%$ patients underwent surgical treatment (Table 4). After this period, the chance of resorption of the ovarian cyst diagnosed in the first trimester decreases. The risk of miscarriage as well as unfavorable effects on the fetus due to the surgery are smaller. On the other hand, surgery after this period is associated with a greater risk of preterm delivery $[16,23]$.

Punctures of adnexal cysts were performed in 3/27 women by abdominal or vaginal route and constituted $11.1 \%$ of adnexal pathologies requiring surgery. There was one case of preterm delivery. The aspiration of simple ovarian cysts during pregnancy is a safe procedure and may prevent the need for surgical intervention. However, in some cases it may appear ultimate option. Depending on the cyst location, the procedure may be performed by vaginal or abdominal route $[24,41,42]$.

In the reviewed meta-analyses, benign neoplasms constituted $90 \%$ of ovarian tumor surgeries. The most frequent among them were mature teratomas (23-37\%), and mucous, serous, and endometrial cystadenomas (8-37\%) $[7,11,42,43]$. Also, in the presented material benign ovarian pathologies accounted for $90 \%$ of the operated ovarian tumors. Among 18 pregnant women operated on for benign ovarian tumors and in one case of cyst puncture, there were 4 cases of mature teratomas $(22.2 \%)$, which was close to $23-37 \%$ presented in the literature. Similarly, the frequency of luteal cysts (16.7\%) ranged within $7-22 \%$ of non-malignant tumor presented in the literature. In contrast, a total of $61.1 \%$ were mucous cystadenomas, cystomas, mucous and serous cysts, and endometrial cyst (Table 2) $[7,11,43,44]$. Acute urinary retention due to retained retroverted uterus and coexisting dermatoid ovarian cyst are rare complications of pregnancy.

The presented case of endometrial cyst of the right ovary, $60 \mathrm{~mm}$ in diameter was noted in a 27 -year-old patient who underwent surgery in 22th hbd, pregnancy III. In pregnancy those cysts tend to resorb (seen on USG). Rapid regression helps confirm benign nature of the observed lesion [20]. The high level of progesterone in pregnancy, temporary cessation of menstrual cycles, and the induction of apoptosis are probably the main causes of endometrios regression $[45,46]$.

The analysis of the material revealed a 1 -fold torsion of the appendages in two cases with left ovarian cyst and peri-salpingeal cyst, a 3-fold adnexal torsion in two pregnant women with right and left ovarian cysts, the torsion of the left fallopian tube with a peri-salpingeal cyst, and right peri-salpingeal cyst.

The review of our material found the torsion of adnexal structures differed from the published data. In our material it was $66.7 \%$ detected on the left side. Among 27 adnexal lesions, there were 6 (22.2\%) cases of torsion. In one case the luteal cyst of the left ovary coexisted with a peri-salpingeal cyst. In other cases, they were ovarian serous cysts and per-salpingeal cysts.

Clinical symptoms of HP are atypical, while ca. 50\% of HP cases may be asymptomatic in the early period. Therefore, early accurate diagnosis is often difficult [28-30]. Transvaginal ultrasound examination is essential in the diagnosis. However, based on literature reviews from 1971-1993 and 1994-2004 it was estimated that approximately 59\% and $74 \%$ of HP cases respectively went undiagnosed before surgery $[31,32]$. In addition to the removal of ectopic pregnancy by laparotomy or laparoscopy, the management options included transvaginal aspiration of the ectopic embryo. However, as HP is very rare the treatment experience is limited [32].

In the presented case of HP, the pregnancy was conceived naturally, and was the sixth in turn after two natural deliveries and three miscarriages (including one gestational trophoblastic disease). Its occurrence was estimated as 1 in 36,000 births, which is similar to the value presented in the literature ( 1 in 30,000 births).

Pregnancy failure in the form of miscarriage after the operation of twisted cyst of the right ovary was associated with a 2-week postponement of surgery, as the woman left the Ward after the diagnosis of her own volition. The operation was not performed until the patient's next hospitalization. Premature births in 31/33 women operated on in pregnancy were reported in $3(9.7 \%)$ cases.

According to current studies monitoring the health of the babies whose mothers underwent surgeries under general endotracheal anesthesia in pregnancy diseases were diagnosed in two (6.5\%) cases. A 32-year old pregnant woman, pregnancy II underwent laparotomy in $17^{\text {th }} \mathrm{hbd}$ for right ovarian mucous cystoma. Her baby daughter born in 38 th hbd, natural delivery, suffers from bronchial asthma diagnosed as early as 3 months after birth. The other 28 -year old patient in her third 
pregnancy was operated on in 18th hbd for bilateral lutein cysts of the ovaries. Her second delivery was natural, and it took place after 40th hbd. Until the age of 10, the daughter's development was uneventful. Tetraparesaspastica manifested in puberty. Those diseases in newborns can hardly be related to negative effects of surgery during pregnancy. Nationwide monitoring of the health status of babies whose mothers underwent surgery in pregnancy would provide an answer to this question and therefore seems to be justified.

Postoperative monitoring of pregnant women who underwent surgical treatment in pregnancy due to malignant tumors, including borderline-types should be obligatory. It is especially important as the patients have been operated on during pregnancy and have undergone fertility-sparing surgery. In our material, two pregnant women were monitored postoperatively, one of them delivered naturally, and the other by Caesarean section. There are no data in the literature indicating the reasons for removal of the ovary and uterus left after giving birth to the planned number of children.

\section{Conclusion}

1. Surgical treatment in pregnancy due to genital disorders should be individualized, taking into account clinical symptoms, gestational age, imaging and laboratory results as well as woman's preferences.

2. Surgical treatment in pregnancy is associated with the risk of complications for the patient and obstetric failures such as miscarriages and premature births.

\section{References}

1. Muller CY, Smith HO (2005) Cervical neoplasia complicating pregnancy. Obstet Gynecol Clin North Am 32: 533-546.

2. Marino T, Cralgo SD (2000) Managing adnexal masses in pregnancy. Contemp $\mathrm{Ob}$ Gyn 45: 130-137.

3. Goffinet F (2001) Ovarian cysts and pregnancy. J Gynecol Obstet Biol Reprod (Paris) 30: S100-108. [Crossref]

4. Aggarwal P, Kehoe S (2011) Ovarian tumours in pregnancy: a literature review. Eur J Obstet Gynecol Reprod Biol 155: 119-124.

5. Marret H, Lhomme C, Lecuru F, Canis M, Lévčque J, et al. (2010) Guidelines for the management of ovarian cancer during pregnancy. Eur J Obstet Gynecol Reprod Biol 149: 18-21. [Crossref]

6. Kondi-Pafiti A, Grigoriadis C, Iavazzo C, Papakonstantinou E, Liapis A, et al. (2012) Clinicopathological characteristics of adnexal lesions diagnosed during pregnancy or cesarean section. Clin Exp Obstet Gynecol 39: 458-461. [Crossref]

7. Oehler MK, Wain GV, Brand A (2003) Gynaecological malignancies in pregnancy: a review. Aust N Z J Obstet Gynaecol 43: 414-420.

8. Pavlidis NA (2002) Coexistence of pregnancy and malignancy. Oncologist 7: 279-287. [Crossref]

9. Ngu SF, Cheung VY, Pun TC (2014) Surgical management of adnexal masses in pregnancy. JSLS 18: 71-75. [Crossref]

10. Mukhopadhyay A, Shinde A, Naik R (2016) Ovarian cysts and cancer in pregnancy. Best Pract Res Clin Obstet Gynaecol 33: 58-72. [Crossref]

11. Giuntoli RL 2nd, Vang RS, Bristow RE (2006) Evaluation and management of adnexal masses during pregnancy. Clin Obstet Gynecol 49: 492-505. [Crossref]

12. Casanova J, Maciel R, Ferreira V, Fernandes E, Rodrigues RM (2013) Borderline Ovarian Tumor during Pregnancy: A Case Report. Case Rep Obstet Gynecol 2013: 160319. [Crossref]

13. Oduncu FS, Kimmig R, Hepp H, Emmerich B (2003) Cancer in pregnancy: maternalfetal conflict. J Cancer Res Clin Oncol 129: 133-146. [Crossref]

14. Cavaco-Gomes J, Moreira CJ, Rocha, Mota R, Paiva V, et al. (2016) Investigation and management of adnexal masses pregnancy. Scientifica (Cairo). 3012802.
15. Tavassoli FA, Devilee P (2003) World Healt Organization classification of tumours Pathology and genetics of tumours of the breast and female genital organs. Lyon. IARC, France: IARC Press; 2003.

16. Weiner E, Mizrachi Y, Keidar R, Kerner R, Golan A, et al. (2015) Laparoscopic surgery performed in advanced pregnancy compared to early pregnancy. Arch Gynecol Obstet 292: 1063-1068

17. Szczepalska M, Rajewski M, Skrzypczak J (2011) The management of ovarian tumors in pregnancy and perinatal outcome. Ginekol Pol 82: 265-271. [Crossref]

18. Hermans RH, Fischer DC, van der Putten HW, van de Putte G, Einzmann T, et al (2003) Adnexal masses in pregnancy. Onkologie 26: 167-172. [Crossref]

19. Zanetta G, Mariani E, Lissoni A, Ceruti P, Trio D, et al. (2003) A prospective study of the role of ultrasound in the management of adnexal masses in pregnancy. BJOG 110 : 578-583. [Crossref]

20. Pateman K, Moro F, Mavrelos D, Foo X, Hoo WL, et al. (2014) Natural history of ovarian endometrioma in pregnancy. BMC Womens Health 14: 128. [Crossref]

21. 21.Glanc P, Salem S, Farine D: Adnexal masses in the pregnant patient: a diagnostic and management challenge. Ultrasound $Q 24: 225-2$

22. Dobroslawa L, Sikora-Szczesniak, Szczesniak G, Sikora W (2006) Leczenie nowotworów germinalnych i gonadalnych jajnika na oddziale ginekologicznopolozniczym. Current Gynecologic Oncology 11: 949-958.

23. Agarwal N, Parul, Kriplani A, Bhatla N, Gupta A (2003) Management and outcome of pregnancies complicated with adnexal masses. Arch Gynecol Obstet 267: 148-152. [Crossref]

24. Condous G, Khalid A, Okaro E, Bourne T (2004) Should we be examining the ovaries in pregnancy? Prevalence and natural history of adnexal pathology detected at firsttrimester sonography. Ultrasound Obstet Gynecol 24: 62-66.

25. Samborska M, Sipak-Szmigiel O, Engel K, Ronin-Walknowska E (2007) Adnexal masses diagnosed during cesarean section in the material of Department of FetoMaternal Medicine of Pomeranian Medical University in years 1977-2007. Klin Perinatol Ginekol 43: 68-70.

26. Ergenoglu M, Yeniel O, Peker N (2011) Peri-salpingeal torsion during pregnancy - case report. Ginekol Pol 82: 287-290.

27. Perkins KM, Boulet SL, Kissin DM (2015) Risk of ectopic pregnancy associated with assisted reproductive technology in the United States, 2001-2011. Obstet Gynecol 125: 70-78.

28. Talbot K, Simpson R, Price N, Jackson SR (2011) Heterotopic pregnancy. J Obstet Gynaecol 31: 7-12. [Crossref]

29. Yu Y, Xu W, Xie Z, Huang Q, Li S (2014) Management and outcome of 25 heterotopic pregnancies in Zhejiang, China. Eur J Obstet Gynecol Reprod Biol 180: 157-161.

30. Sun SY, Araujo JE, Elito JJ, Rolo LC, Camparharo FF, et al. (2012) Diagnosis of heterotopic pregnancy using ultrasound and magnetic resonance imaging in the first trimester of pregnancy: a case report. Case Rep Radiol 317592.

31. Barrenetxea G, Barinaga-Rementeria L, Lopez de Larruzea A, Agirregoikoa JA, Mandiola M, et al. (2007) Heterotpic pregnancy: two cases and a comparative review. Fertil Steril 87: 417.e9-15.

32. Li JB, Kong LZ, Yang JB, Niu G, Fan L, et al. (2016) Management of Heterotopic Pregnancy: Experience From 1 Tertiary Medical Center. Medicine (Baltimore) 95: e2570. [Crossref]

33. Ligon AH, Morton CC (2000) Genetics of uterine leiomyomata. Genes Chromosomes Cancer 28: 235-245. [Crossref]

34. Kowalska-Koprek U, Kus E, Berner-Trabska M, Nawarra D, Kulik V, et al. (2004) Huge uterine myoma complicated the pregnancy in 47-year old pregnant woman. Case report and review of the literature. Prz Menopauzal 4: 53-55.

35. Mogos MF, Salihu HM, Aliyu MH, Whiteman VE, Sultan DH (2013) Association between reproductive cancer and fetal outcomes: a population-based study. Int $J$ Gynecol Cancer 23: 218-226.

36. Abu-Heija AT, Jallad MF, Abukteish F (2000) Maternal and perinatal outcome of pregnancies after the age of 45. J Obstet Gynaecol Res 26: 27-30. [Crossref]

37. Ziadeh SM (2002) Maternal and perinatal outcome in nulliparous women aged 35 and older. Gynecol Obstet Invest 54: 6-10. [Crossref] 
38. Kasai M, Koh B, Hanabusa K, Nakamura T (2015) Fetal effects of laparoscopic surgery during pregnancy. Jsgoe 30: 391-395.

39. Yumi H (2008) Guidelines for diagnosis, treatment, and use of laparoscopy for surgical problems during pregnancy: This statement was reviewed and approved by the Board of Governors of the Society of American Gastrointestinal and Endoscopic Surgeons (SAGES), September 2007. It was prepared by the SAGES Guidelines Committee. Surg Endosc 22: 849-861.

40. de Bakker JK, Dijksman LM, Donkervoort SC (2011) Safety and outcome of general surgical open and laparoscopic procedures during pregnancy. Surg Endosc 25: 15741578 .

41. Knudsen UB, Tabor A, Mosgaard B, Andersen ES, Kjer JJ, et al. (2004) Management of ovarian cysts. Acta Obstet Gynecol Scand 83: 1012-1021. [Crossref]
42. Caspi B, Ben-Arie A, Appelman Z, Or Y, Hagay Z, et al. (2000) Aspiration of simple pelvic cysts during pregnancy. Gynecol Obstet Invest 49: 102-105.

43. Hoover K, Jenkins TR (2011) Evaluation and management of adnexal mass in pregnancy. Am J Obstet Gynecol 205: 97-102. [Crossref]

44. Yacobozzi M, Nguyen D, Rakita D (2012) Adnexal masses in pregnancy. Semin Ultrasound CT MR 33: 55-64. [Crossref]

45. Meresman GF, Auge L, Baranao RI, Lombardi E, Tesone M, et al. (2002) Ora contraceptives suppress cell proliferation and enhance apoptosis of eutopic endometrial tissue from patients with endometriosis. Fertil Steril 77: 1141-1147.

46. Davis L, Kennedy SS, Moore J, Prentice A (2007) Modern combined oral contraceptives for pain associated with endometriosis. Cochrane Database Syst Rev 18: CD001019.

Copyright: (2019 Sikora-Szczesniak DL. This is an open-access article distributed under the terms of the Creative Commons Attribution License, which permits unrestricted use, distribution, and reproduction in any medium, provided the original author and source are credited. 